\title{
The Trajectory of the Anthropocene: the Great Acceleration
}

Authors: Will Steffen1,2, Wendy Broadgate3, Lisa Deutsch1, Owen Gaffney3, Cornelia Ludwig1

\begin{abstract}
The "Great Acceleration" graphs, originally published in 2004 to show socioeconomic and Earth System trends from 1750 to 2000, have now been updated to 2010. In the graphs of socio-economic trends, where the data permit, the activity of the wealthy (OECD) countries, those countries with emerging economies, and the rest of the world have now been differentiated. The dominant feature of the socioeconomic trends is that the economic activity of the human enterprise continues to grow at a rapid rate. However, the differentiated graphs clearly show that strong equity issues are masked by considering global aggregates only. Most of the population growth since 1950 has been in the non-OECD world but the world's economy (GDP), and hence consumption, is still strongly dominated by the OECD world. The Earth System indicators, in general, continued their long-term, postindustrial rise, although a few, such as atmospheric methane concentration and stratospheric ozone loss, showed a slowing or stabilisation over the past decade. The post-1950 acceleration in the Earth System indicators remains clear. Only beyond the mid- $20^{\text {th }}$ century is there clear evidence for fundamental shifts in the state and functioning of the Earth System that are beyond the range of variability of the Holocene and driven by human activities. Thus, of all the candidates for a start date for the Anthropocene, the beginning of the Great Acceleration is by far the most convincing from an Earth System science perspective.
\end{abstract}




\section{Origins}

What have now become known as the "Great Acceleration" graphs were originally designed and constructed as part of the synthesis project of the International Geosphere-Biosphere Programme (IGBP), undertaken during the 1999-2003 period. The synthesis aimed to pull together a decade of research in IGBP's core projects, and, importantly, generate a better understanding of the structure and functioning of the Earth System as a whole, more than just a description of the various parts of the Earth System around which IGBP's core projects were structured. The increasing human pressure on the Earth System was a key component of the synthesis.

The project was inspired by the proposal in 2000 by Paul Crutzen, a Vice-Chair of IGBP, that the Earth had left the Holocene and entered a new geological epoch, the Anthropocene, driven by the impact of human activities on the Earth System (Crutzen and Stoermer 2000; Crutzen 2002). Crutzen suggested that the start date of the Anthropocene be placed near the end of the $18^{\text {th }}$ century, about the time that the industrial revolution began, and noted that such a start date would coincide with the invention of the steam engine by James Watt in 1784.

As part of the project, the synthesis team wanted to build a more systematic picture of the human-driven changes to the Earth System, drawing primarily, but not exclusively, on the work of the IGBP core projects. The idea was to record the trajectory of the "human enterprise" through a number of indicators and, over the same timeframe, track the trajectory of key indicators of the structure and functioning of the Earth System. Inspired by Crutzen's proposal for the Anthropocene, we chose 1750 as the starting date for our trajectories to ensure that we captured the beginning of the industrial revolution and the changes that it wrought. We took the graphs up to 2000, the most recent year that we had data for many of the indicators. The graphs, first published in the IGBP synthesis book (Steffen et al. 2004), consisted of 12 indicators for the human enterprise and 12 for features of the Earth System.

We expected to see a growing imprint of the human enterprise on the Earth System from the start of the industrial revolution onwards. We didn't, however, expect to see the dramatic change in magnitude and rate of the human imprint from about 1950 onwards. That phenomenon was already well known to historians such as John McNeill (2000) but generally not to Earth System scientists. The post-1950 acceleration was noted in the IGBP synthesis book as:

"One feature stands out as remarkable. The second half of the twentieth century is unique in the entire history of human existence on Earth. Many human activities reached take-off points sometime in the twentieth century and have accelerated sharply towards the end of the century. The last 50 years have without doubt seen the most rapid transformation of the human relationship with the natural world in the history of humankind" (Steffen et al. 2004, p. 131).

The term "Great Acceleration” was first used in a working group of a 2005 Dahlem Conference on the history of the human-environment relationship (Hibbard et al. 2006). The term echoed Karl Polanyi's phrase “The Great Transformation”, and in his book by the same name (Polanyi 1944) Polanyi put forward a holistic understanding of the nature of modern societies, including mentality, behaviour, structure and more. 
In a similar vein, the term "Great Acceleration" aims to capture the holistic, comprehensive and interlinked nature of the post-1950 changes simultaneously sweeping across the socio-economic and biophysical spheres of the Earth System, encompassing far more than climate change.

The Dahlem working group was chaired by one of us (WS) and included both Paul Crutzen and John McNeill. The term was first used in a journal article in 2007 (Steffen et al. 2007), in which several stages of the Anthropocene were proposed and the 12 human enterprise graphs were reprinted.

The Great Acceleration graphs have since become an iconic symbol of the Anthropocene, and have been reprinted many times and in many different academic and cultural fora and media, (for example globaia.org, wanderinggaia.com, visualizing.org, anthropocene.info, new scientist (http://www.newscientist.com/article/dn14950-special-report-the-facts-aboutoverconsumption.html\#.VCVmXef4Lew) and form the basis for the data visualization, Welcome to the Anthropocene, http://vimeo.com/39048998). A version of the Great Acceleration graphs even appeared in Dan Brown's novel Inferno.

The post-1950 acceleration of the human imprint on the Earth System, particularly the 12 graphs that show changes in Earth System structure and functioning, have played a central role in the discussion around the formalisation of the Anthropocene as the next epoch in Earth history. Although there has been much debate around the proposed start date for the Anthropocene, the beginning of the Great Acceleration has been a leading candidate (Zalasiewicz et al. 2012).

Here we update, extend to 2010, analyse, and discuss the significance of the Great Acceleration graphs, including their relevance for the definition of the start date of the Anthropocene. Where the data permit, in the 12 graphs of socio-economic trends we differentiate the activity of the wealthy (OECD) countries, those countries with emerging economies, and the rest of the world. These graphs with "splits" are important in exploring equity issues in terms of the differential pressures that various groups of countries apply to the Earth System and how the distribution of these pressures among groups is changing through time.

\section{Updating the graphs: methodology}

In updating the Great Acceleration graphs we aimed to maximise comparability by retaining, wherever possible, the same indicators that we used in the original 24 graphs. For the socio-economic trends we chose indicators that capture the major features of contemporary society. The original 12 included indicators for population, economic growth, resource use, urbanisation, globalisation, transport and communication. We have retained 11 of the original 12 graphs. The only change was to remove the number of McDonald's restaurants, which we used as an indicator for globalisation, and replace it with primary energy use. The combination of foreign direct investment, international tourism and telecommunication gives some sense of the rapidly increasing degree of globalisation and connectivity. Primary energy use is a key indicator that relates directly to the human imprint on the functioning of the Earth System and is a central feature of contemporary society. 
We first present the updated socio-economic trends in Figure 1 as global aggregates as in the original set of 12 socio-economic graphs. We have also now, where the data permit, split 10 of the socio-economic graphs into trends for the OECD countries, for the so-called BRICS countries (Brazil, Russia, India, China (including Macau, Hong Kong and Taiwan where applicable) and South Africa), and for the rest of the world (Figure 2). OECD members are here defined as countries that were members in 2010 and their membership status was applied to the whole data set, which in some cases goes as far back as 1750 .

The 12 Earth-System indicators track change in major features of the system's structure and functioning - atmospheric composition, stratospheric ozone, the climate system, the water and nitrogen cycles, marine ecosystems, land systems, tropical forests, and terrestrial biosphere degradation. Other good candidates could be found, for example percentage Arctic sea-ice loss, but our aim is to show general, long-term trends at a broad systemic level. Furthermore, the availability of long-term data sets limited the choice of parameters (see below).

We have retained 11 of the 12 features of the Earth System's structure and functioning that were used in the original graphs, but the specific indicators have changed in a couple of cases. For example, the indicator for ocean ecosystems is now marine fish capture in million tonnes, replacing the percentage of fisheries fully exploited. For biodiversity loss - or more appropriately, the change in biosphere integrity - the indicator is now percentage decrease in modelled mean species abundance (actually an indicator of the aggregated human pressure on the terrestrial biosphere), replacing the modelled number of species extinctions. We have removed the number of great floods from the set of 12 graphs and replaced it with ocean acidification. As an indicator for change in biogeochemical flows, we have retained the modelled human-induced perturbation flux of nitrogen into the coastal margin as it is the only published analysis of the temporal evolution of this or similar trends over the 1950-2010 period. This graph could be updated in the near future based on global watershed models using databases of observed fluxes of nitrogen through river basins (Seitzinger et al. 2005). The change in surface temperature is the only trend that directly tracks changes in the climate system, although of course changes in the atmospheric concentrations of the three most important long-lived greenhouse gases, and ocean acidification, are closely related. The updated Earth-System trends are shown in Figure 3.

There are challenges with sourcing and merging datasets to show global trends over two-and-a-half centuries. Data availability and access have improved significantly since the original graphs were produced; however, there are still major challenges of incomplete and inaccessible datasets, changing methodologies (e.g., the combining of data sets) and data coverage. In this update we provide full datasets as supplementary material with web links and references to the sources of these data to facilitate quality control and further analysis. We worked closely with data originators on the selection, smoothing and merging of data so that each dataset was treated in an appropriate manner (see figure captions and supplementary material for details). In many cases measurements are superimposed on the modelled and smoothed trends in the supplementary material. However, we are unable in most cases to check the reliability of underlying raw data since there is rarely more than one source of that data. 
Models were used to provide a long-term view of various well-understood trends (tropical forest loss, domesticated land, terrestrial biosphere degradation, nitrogen to the coastal zone, water withdrawal and ocean acidification). However, long-term data are simply not available, for example, for marine fish capture, shrimp aquaculture and stratospheric ozone loss. For global temperature, a longer term trend pre-1850 is available from the palaeo record. However, this is not calibrated, so we chose to focus on the instrumental record.

Our data are unique in that they cover, where possible, the period 1750-2010. Other datasets that exist over parts - and in some cases all - of these periods are consistent with our data. Some examples are global and urban population; the data we present here from the History Database of the Global Environment (HYDE, Klein Goldewijk 2010) are consistent with other sources (FAOStat and World Bank). Our fertilizer consumption graph (IFA database) maps exactly onto the FAOStat for the portions that overlap. Our domestic land plot (Pongratz et al. 2008) is consistent with the HYDE 3.1 distribution of cropland plus pasture (Klein Goldewijk et al. 2011) and indeed our reconstructed domesticated land and tropical forest are calculated using land use change estimates including those from HYDE (Klein Goldewijk 2011).

\section{Extending the Great Acceleration to 2010}

Because the aggregated socio-economic and Earth System trends are multi-decadal, the effect of adding the most recent decade, from 2001 to 2010, onto the long-term trends needs to be interpreted with caution. One decade is too short to define longterm shifts in the trends. Nevertheless, the most recent decade, in addition to showing a continuation of most of the trends begun at the mid-20 century, is beginning to show some slowing in a few areas.

The dominant feature of the socio-economic trends is that the economic activity of the human enterprise continues to grow at a rapid rate. The Global Financial Crisis of 2008-2009 may be just discernible at the end of the global GDP curve but it is more clearly visible as a sharp downturn during the last decade in foreign direct investment. Recovery has been rapid, however. Also, there may be a slowing in the construction of new large dams. However, remaining global indicators show no signs of slowing in the most recent decade. Primary energy use shows the shape typical of the Great Acceleration trajectory but shows little or no evidence of an effect of the Global Financial Crisis.

Population continued to grow strongly through the 2001-2010 period with little sign of slowing. However, changes in fertility rates foreshadow that exponential population growth will soon be over. Global average fertility rate has dropped to 2.5 children per woman. Humanity has passed "peak child" and population is expected to reach between 10 and 11 billion people later this century (UN DESA 2014), though some uncertainty remains. Gerland et al. (2014) project a population of between 9.6 and 12.3 billion by 2100 .

Resource use has continued to grow through the most recent decade. Global fertilizer consumption, paper production and water use have all risen. The number of large 
dams, however, has shown a strong leveling over the last 10-15 years. This will probably become a longer-term trend because the number of large dams that can be built is limited by the finite number of large rivers. We are probably approaching that limit, so the continuing increase in water use is likely driven by increasing extraction of groundwater (Shah et al. 2007).

Transport, as measured by the number of motor vehicles, and international tourism continue their explosive post-1950 growth. Telecommunications show even more explosive growth but the take-off point for that trend was around 1990, driven largely by the mobile phone industry.

One of the most important trends of all is the rapid rate of urbanisation. The move from rural to urban living began its contemporary rise in the late 1800s and its rate has steadily increased since then, rising more sharply around 1950 and continuing to the present. About 2008 humanity passed an historic milestone: over $50 \%$ of the global population now live in urban areas (Seto et al. 2010). On current trajectories there will be more urban areas built during the first three decades of the 21st century than in all of previous history combined (Seto et al. 2012).

The Earth System indicators also, in general, continued their long-term, postindustrial rise, although there are some interesting variations. The atmospheric concentrations of the three, long-lived greenhouse gases - carbon dioxide, nitrous oxide, and methane - all increased through the decade, although methane at a slower rate than the other two. The rise in carbon dioxide concentration parallels closely the rise in primary energy use and in GDP, showing no sign yet of any significant decoupling of emissions from either energy use or economic growth (Friedlingstein et al. 2014).

Atmospheric methane leveled out in the late 1990s, indicating that emissions (from natural wetlands and anthropogenic waste, agriculture and biomass burning) were in balance with the sinks (reaction in the atmosphere and absorption by soils), and increased again from 2007. The exact reasons for the stabilisation and subsequent increase are debated, but the IPCC AR5 reports that the recent increase is most likely caused by high temperatures in the Arctic and increased precipitation in the tropics (Ciais et al. 2013).

The relationship between the rising concentrations of greenhouse gases in the atmosphere and the warming of the climate system is now well documented, well understood and beyond reasonable doubt (IPCC 2013). Here we use the global average surface air temperature as the indicator of the state of the climate system, and it clearly shows the warming of the climate system, including the strong rise from about 1970 to 2000, and the so-called "hiatus" from about 2000 to the end of the graph (IPCC 2013).

The ocean currently absorbs about a quarter of the carbon dioxide added to the atmosphere from human activities each year (Le Quéré et al. 2009). This leads to ocean acidification, which tracks the carbon dioxide curve closely. Whilst the ocean uptake of carbon dioxide significantly reduces its impact on climate, it causes marine ecosystems and biodiversity to change. For example, corals and shellfish are finding it more difficult to build their shells (Gattuso and Hansson 2011). 
There are several trends that show signs of slowing or stabilisation, but the reasons for these developments are likely to be different. One such trend is the stabilisation of the ozone hole from about 1990, continuing to the present. In September 2014 the World Meteorological Organization reported: "Total column ozone declined over most of the globe during the $1980 \mathrm{~s}$ and early $1990 \mathrm{~s}$ (by about $2.5 \%$ averaged over $60^{\circ} \mathrm{S}$ to $60^{\circ} \mathrm{N}$ ). It has remained relatively unchanged since 2000, with indications of a small increase in total column ozone in recent years, as expected. In the upper stratosphere there is a clear recent ozone increase, which climate models suggest can be explained by comparable contributions from declining ODS [ozone-depleting substances] abundances and upper stratospheric cooling caused by carbon dioxide increases" (WMO 2014).

The stabilisation of stratospheric ozone over the southern high latitudes is an oft-cited example of an effective human policy response to a global environmental problem. The report projects: "Total column ozone will recover toward the 1980 benchmark levels over most of the globe under full compliance with the Montreal Protocol. This recovery is expected to occur before midcentury in mid-latitudes and the Arctic, and somewhat later for the Antarctic ozone hole” (WMO 2014).

A similar trend is the stagnation of marine fish capture since the late 1980s. Here the bending of the curve is not due to marine stewardship, but to the exhaustion of the world's marine fish stocks from the increasing fishing pressure that is evident from the start of the dataset. This reason is supported by the observation that the amount of fish catch per unit effort is decreasing sharply; that is, it is taking more and more effort to capture the same amount of fish (Meyers and Worm 2003). Data on catch per 100 hooks for large predatory fish over time show a similar shape, but in the opposite direction, to the Great Acceleration figures (Meyers and Worm 2003), indicating the removal of essentially $90 \%$ of the large predators in all seas on the globe and the essential collapse of some species, for example, Newfoundland cod.

The leveling off of marine fish capture does not equate to a leveling off of human consumption of marine fish. The explosive rise of aquaculture (note the very rapid rise in shrimp aquaculture in Figure 3 as an example of this trend) has ensured that a steadily increasing amount of marine fish has continued to be available for human consumption despite the exhaustion of marine fisheries. In essence, the growth of aquaculture is an attempt to replace this decline with species that we want to consume but can no longer fish. Technology and trade could not extract more fish from the wild seas but have enabled us to grow livestock in the ocean. Aquaculture is the fastest growing food sector today and $50 \%$ of global fisheries consumption is aquaculture-based.

The switch to aquaculture, however, has its own environmental problems. One of the most important is the need to capture wild fish further down the food chain as feed for carnivorous fish raised in aquaculture (Deutsch et al. 2011), which, unless managed carefully, can weaken the resilience of the global food system (Troell et al. 2014).

The amount of domesticated land is a third trend that shows a significant slowing, starting about 1950 and continuing through the most recent decade. Domesticated land refers to human-dominated landscapes - cities, croplands, heavily managed 
grazing lands - that have been converted from more natural biomes, such as forests, savannas and grasslands. The slower trend largely reflects an intensification of agriculture as the amount of available arable land dwindles, much like the exhaustion of the world's marine fisheries. In recent decades what land has been domesticated has mainly been at the expense of tropical forests, as shown by the increasing area of such forest that has been lost, a trend that has continued through the most recent decade.

\section{Deconstructing the socio-economic trends: the equity issue}

The original Great Acceleration graphs (Steffen et al. 2004) treated humanity as an aggregated whole and did not attempt to deconstruct the socio-economic graphs into countries or groups of countries. This approach - and the common treatment of humanity as a whole in discourses about the Anthropocene - has prompted some sharp criticism from social scientists and humanities scholars that such treatment masks important equity issues (e.g., Malm and Hornborg 2014). In this update the socio-economic graphs with splits (Figure 2) help to address these concerns.

The most striking insight from Figure 2 is that most of the population growth has been in the non-OECD world but the world's economy (GDP) is still strongly dominated by the OECD world. Despite the shift of global production, traditionally based within OECD countries, towards the BRICS nations, the bulk of economic activity, and with it, the lion's share of consumption, remain largely within the OECD countries. In 2010 the OECD countries accounted for 74\% of global GDP but only $18 \%$ of the global population. Insofar as the imprint on the Earth System scales with consumption, most of the human imprint on the Earth System is coming from the OECD world. This points to the profound scale of global inequality, which distorts the distribution of the benefits of the Great Acceleration and confounds efforts to deal with its impacts on the Earth System.

The Great Acceleration graphs themselves, along with the splits, challenge a commonly held view of "what's new about the Anthropocene?" - predicated on the notion that humans have always changed their environment. While it is certainly true humans have always altered their environment, sometimes on a large scale, what we are now documenting since the mid- $20^{\text {th }}$ century is unprecedented in its rate and magnitude. Furthermore, by treating "humans" as a single, monolithic whole, it ignores the fact that the Great Acceleration has, until very recently, been almost entirely driven by a small fraction of the human population, those in developed countries.

As the middle classes in the BRICS nations grow, this is beginning to change. The shift is already emerging in the trajectories of several indicators. For example, most of the post-2000 rise in paper production, telecommunication devices and motor vehicle number has occurred in the non-OECD world (Figure 2). In fact, we see a leveling of the trajectory of water use, fertilizer consumption and paper production in OECD countries. Since about 1970 most of the increase in fertilizer consumption has occurred in BRICS nations. Although not shown in the figures, the shift in the sources of greenhouse gas emissions has been dramatic. Around 2006 China became the largest emitter of carbon dioxide, overtaking the United States. By 2013 per capita 
emissions in China (7.2 tonnes of $\mathrm{CO}_{2}$ per person per year) surpassed per capita emissions in Europe (6.8 tonnes of $\mathrm{CO}_{2}$ per person per year) (Friedlingstein et al. 2014).

However, despite the contribution of these and other developments to bringing many people in the non-OECD world out of absolute poverty, inequalities in income and wealth both within and between countries continue to be a significant problem, with consequences for individual and societal well-being (Wilkinson and Pickett 2009). Furthermore, because the effects of the Great Acceleration on the functioning of the Earth System are cumulative over time, most clearly evident in the climate system, the historic inequalities embedded in the origin and trajectory of the Great Acceleration continue to plague negotiations to deal with its consequences.

The splits show other significant changes in the socioeconomic trends amongst groups of nations. For example, the rapid expansion in urbanisation will take place mainly in Asia and Africa. Between 1978 and 2012 China's urban population swelled from $17.9 \%$ to $52.6 \%$ and the country is on course for an urban population of over one billion people within two decades (Bai et al. 2014). In a practical sense, the future trajectory of the Anthropocene may well be determined by what development pathways urbanisation takes in the coming decades, particularly in Asia and Africa.

The is also evidence of technological leapfrogging, which offers some hope that the post-World War II development pathway followed by the OECD countries, which has driven the Great Acceleration, does not necessarily have to be followed by other nations. For example, the very rapid rise in phone subscriptions since 2000 has occurred almost entirely in BRICS countries and the rest of the world, and these have predominantly been for mobile devices, thus leapfrogging over the need to build and support landline infrastructure across entire nations.

It remains to be seen whether similar leapfrogging can occur in the electricity generation sector; that is, whether distributed systems based on renewable energy technologies will be developed rather than centralized grid systems based on large fossil-fuel generation plants. Furthermore, developing countries have the opportunity to avoid poor planning decisions made in the West that have led to high levels of air pollution, for example, and costly remediation. However, at present urbanisation trends in Asia appear to be following the North American model (Seto 2010).

\section{Implications of the Great Acceleration for the Anthropocene discourse}

The Great Acceleration graphs have important implications for the two central questions that are driving the Anthropocene discourse. First, are the impacts of human activities on the structure and functioning of the Earth System profound enough to distinguish the present state of the system from the Holocene? In other words, is there convincing evidence that a new time period in Earth history is justified? Second, if so, when is the most appropriate start date for the new time period?

The socio-economic Great Acceleration graphs (Figure 1) clearly show the phenomenal growth of the human enterprise after World War II, both in economic activity, and hence consumption, and in resource use. The corresponding Earth 
System graphs (Figure 3) also show significant changes in rates or states of all parameters in the $20^{\text {th }}$ century, although a mid-century sharp acceleration is not so clearly defined in all of them. Nevertheless, the coupling between the two sets of 12 graphs is striking. Correlation in time does not prove cause-and-effect, of course, but there is a vast amount of evidence that the changes in the structure and functioning of the Earth System shown in Figure 3 are primarily driven by human activities (e.g., IPCC 2013; Galloway et al. 2008; Rowland 2006; MA 2005; Steffen et al. 2004).

Human causation of the trends in Figure 3 does not, however, directly address the question of whether the present state of the Earth System is clearly different from the Holocene. For most of the individual graphs in Figure 3, though, there is convincing evidence that the parameters have moved well outside of the Holocene envelope of variability (Rockström et al. 2009; Steffen et al. 2014).

The atmospheric concentrations of the three greenhouse gases - carbon dioxide, nitrous oxide and methane - are now well above the maximum observed at any time during the Holocene (Ciais et al. 2013). There is no evidence of a significant decrease in stratospheric ozone anytime earlier in the Holocene. Nor is there any evidence that human impact on the marine biosphere, as measured by global tonnage of marine fish capture, has been anywhere near the late $20^{\text {th }}$ century level at any time earlier in the Holocene. The nitrogen cycle has been massively altered over the past century (Galloway and Cowling 2002; Galloway et al. 2008) following the discovery in the early 1900s of the Haber-Bosch process that creates fertilizer from unreactive atmospheric nitrogen. The nitrogen cycle is now operating well outside of its Holocene range, if the pre-industrial nitrogen cycle can be taken as an approximation for the Holocene nitrogen cycle (Galloway and Cowling 2002). Ocean carbonate chemistry is likely changing faster than at any other time in the last 300 million years (Hönisch et al. 2012) and biodiversity loss may be approaching mass extinction rates (Barnosky et al. 2012).

Over the 1901-2012 period global average surface temperature increased by nearly $0.9^{\circ} \mathrm{C}$ (IPCC 2013); in the Northern Hemisphere the current 30-year average temperature is likely the highest for the last 1400 years (IPCC 2013). Based on a recent compilation of proxy temperature data, the global mean temperature from 86ka BP was about $0.7^{\circ} \mathrm{C}$ above pre-industrial (Marcott et al. 2013), suggesting that the global climate is also now beyond the Holocene envelope of variability.

Human modification of the terrestrial biosphere has had a much longer history than our imprint on other components of the Earth System, a common argument for the "what's new about the Anthropocene?" view. There is a rich record of this imprint over millennia, prompting some to suggest a very early start to the Anthropocene (e.g., Edgeworth et al. 2014), perhaps even earlier than the Holocene itself. However, these approaches are based only on records of the human imprint on the terrestrial biosphere and do not relate these to significant changes in the structure or functioning of the Earth System as a whole. The exception to this is the proposal that early agricultural activities in the mid-Holocene period emitted enough carbon dioxide and methane to raise global average temperatures significantly and prevent the onset of an ice age (Ruddiman 2003; Ruddiman et al. 2014). The weight of evidence, however, argues that the mid-Holocene rise in carbon dioxide was a result of natural variability and not human agency (Masson-Delmotte et al. 2013). Furthermore, analysis of 
orbital forcing parameters shows that an ice age was not imminent at the midHolocene and that the Holocene is expected to be an unusually long interglacial period (Loutre and Berger 2000).

The beginning of the Industrial Revolution around the late $18^{\text {th }}$ century is sometimes proposed as a start date for the Anthropocene (Crutzen 200). Its importance as the beginning of large-scale use by humans of a new, powerful, plentiful energy source fossil fuels - is unquestioned. Its imprint on the Earth System is significant and clearly visible on a global scale. However, while its trace will remain in geological records, the evidence of large-scale shifts in Earth System functioning prior to 1950 is weak.

Of all the candidates for a start date for the Anthropocene, the beginning of the Great Acceleration is by far the most convincing from an Earth System science perspective. It is only beyond the mid-20 $0^{\text {th }}$ century that there is clear evidence for fundamental shifts in the state and functioning of the Earth System that are (i) beyond the range of variability of the Holocene, and (ii) driven by human activities and not by natural variability.

A mid-20 $0^{\text {th }}$ century start date for the Anthropocene has an important implication, as shown in Figure 2 and discussed in Section 4. An early-mid Holocene, or even earlier, start date for the Anthropocene would tend to diminish the importance of equity issues, so prominent in the Great Acceleration, and reinforce the notion of "humanity as a whole". The situation is beginning to change, though, as the Great Acceleration spreads to China, India, Russia, Brazil, South Africa, Indonesia and other countries. In the $21^{\text {st }}$ century, "humanity as a whole" is edging closer to becoming a reality.

Setting the start date of the Anthropocene at the beginning of the Great Acceleration makes it possible to specify the onset of the Anthropocene with a high degree of precision (Zalasiewicz et al. 2012). On Monday 16 July 1945, about the time that the Great Acceleration began, the first atomic bomb was detonated in the New Mexico desert. Radioactive isotopes from this detonation were emitted to the atmosphere and spread worldwide entering the sedimentary record to provide a unique signal of the start of the Great Acceleration, a signal that is unequivocally attributable to human activities.

In summary, the Great Acceleration marks the phenomenal growth of the global socio-economic system, the human part of the Earth System. It is difficult to overestimate the scale and speed of change. In little over two generations - or a single lifetime - humanity (or until very recently a small fraction of it) has become a planetary-scale geological force. Hitherto human activities were insignificant compared with the biophysical Earth System, and the two could operate independently. However, it is now impossible to view one as separate from the other. The Great Acceleration trends provide a dynamic view of the emergent, planetaryscale coupling, via globalisation, between the socio-economic system and the biophysical Earth System. We have reached a point where many biophysical indicators have clearly moved beyond the bounds of Holocene variability. We are now living in a no-analogue world. 


\section{The future of the Great Acceleration}

Can the Great Acceleration in its present form continue indefinitely? This seems to be the dominant narrative in the post-World War II era, where continual economic growth as measured by increases in GDP and ongoing technological development are assumed to be the norm. However, the history of human development shows that "... we might find a human history marked by crises, regime shifts, disasters and constantly changing patterns of adjustments to limits and confines. Indeed, this now emerges as a new historical meta-narrative....” (Sörlin and Warde 2007). In fact, periods of growth, then collapse, followed by reorganisation is a common pattern in the human past (Costanza et al. 2006).

There are several glimmers of hope that the growth/collapse pattern may be avoided. As noted in Section 3, exponential population growth is over and global population seems more likely to stabilise this century. Regulation of chlorofluorocarbons (CFCs) through the Montreal Protocol has resulted in early signs of recovery of Antarctic stratospheric ozone (Figure 1). Policies in OECD countries to regulate excessive use of fertilizers have stabilised their consumption in these nations. The amount of domesticated land is increasing more slowly as agricultural intensification takes over (albeit with pollution problems from excessive use of nitrogen and phosphorus fertilizers in some agricultural zones (Steffen et al. 2014)). The rapid rise of mobile telecommunication devices in the developing world is an excellent example of leapfrogging. If such leapfrogging could be extended to energy systems, the developing world may lead the way in decoupling development from environmental impacts.

On the other hand, greenhouse gases are still rising rapidly, threatening the stability of the climate system, and tropical forest and woodland loss remains high. The pursuit of growth in the global economy continues, but responsibility for its impacts on the Earth System has not been taken. Planetary stewardship has yet to emerge.

Will the next 50 years bring the Great Decoupling or the Great Collapse? The latest 10 years of the Great Acceleration graphs show signs of both but cannot distinguish between these scenarios, or other possibilities. But 100 years on from the advent of the Great Acceleration, in 2050, we'll almost certainly know the answer.

\section{Acknowledgements:}

The original Great Acceleration graphs are based on the research of the International Geosphere-Biosphere Programme. We thank Olivier Rousseau, International Fertilizer Industry Association, Richard Feely (NOAA, US), Dana Greely (NOAA, US). Sybil Seitzinger (IGBP), Ninad Bondre (IGBP), Richard Grainger (FAO), Thorsten Kiefer (IGBP PAGES), Ray Bradley (University of Massachusetts), Max Troell (Beijer Institute) and Marc Metian (Stockholm Resilience Centre) for their contributions to updating the graphs. We also thank reviewers and the editor for very useful comments on an earlier version of the manuscript. 



\section{Figure Captions}

Figure 1. Trends from 1750 to 2010 in globally aggregated indicators for socioeconomic development.

\section{Title: Population}

Unit: billion

Caption: Global population data according to the HYDE (History Database of the Global Environment) database. Data before 1950 are modeled. Data are plotted as decadal points.

Sources: HYDE database 2013; Klein Goldewijk et al. 2010.

\section{Title: Real GDP}

Unit: trillion US real 2010 dollars

Caption: Global real GDP (Gross Domestic Product) in year 2010 US dollars. Data are a combination of Maddison for the years 1750 to 2003 and Shane for 1969-2010. Overlapping years from Shane data are used to adjust Maddison data to 2010 US dollars.

Sources: Maddison 1995; M. Shane, Research Service, United States Department of Agriculture (USDA); Shane 2014.

\section{Title: Foreign direct investment}

Unit: trillion US dollars

Caption: Global Foreign direct investment in current (accessed 2013) US dollars based on two data sets: IMF (International Monetary Fund) from 1948-1969 and UNCTAD (United Nations Conference on Trade and Development) from 1970-2010. Sources: IMF 2013; UNCTAD 2013.

\section{Title: Urban population}

Unit: billion

Caption: Global urban population data according to the HYDE database. Data before 1950 are modeled. Data are plotted as decadal points.

Sources: HYDE database 2013; Klein Goldewijk et al. 2010.

\section{Title: Primary energy use}

\section{Unit: Exajoule (EJ)}

Caption: World primary energy use. 1850 to present based on Grubler et al. 2012 1750-1849 data are based on global population using 1850 data as a reference point. Sources: A. Grubler, International Institute for Applied Systems Analysis (IIASA); Grubler et al. 2012.

\section{Title: Fertilizer consumption}

\section{Unit: million tonnes}

Caption: Global fertilizer (nitrogen, phosphate and potassium) consumption based on International Fertilizer Industry Association (IFA) data.

Sources: Olivier Rousseau, IFA; IFA database.

\section{Title: Large dams}

Unit: thousand dams 
Caption: Global total number of existing large dams (minimum $15 \mathrm{~m}$ height above foundation) based on the ICOLD (International Committee on Large Dams) database Source: ICOLD database register search. Purchased 2011.

\section{Title: Water use}

Unit: thousand $\mathrm{km}^{3}$

Caption: Global water use is sum of irrigation, domestic, manufacturing and electricity water withdrawals from 1900 to 2010 and livestock water consumption from 1961-2010. The data are estimated using the WaterGAP model.

Source: M. Flörke, Center for Environmental Systems Research, University of Kassel; Flörke et al. 2013; aus der Beek et al. 2010; Alcamo et al. 2003.

\section{Title: Paper production}

Unit: million tonnes

Caption: Global paper production from 1961 to 2010.

Sources: Based on FAO on-line statistical database FAOSTAT.

\section{Title: Transportation}

Unit: million motor vehicles

Caption: Global number of new motor vehicles per year. From 1963-1999 data include passenger cars, buses and coaches, goods vehicles, tractors, vans, lorries, motorcycles and mopeds. Data 2000-2009 include cars, buses, lorries, vans and motorcycles.

Sources: IRF (International Road Federation) 2011.

\section{Title: Telecommunications}

Unit: billion telephone subscriptions

Caption: Global sum of fixed landlines (1950-2010) and mobile phone subscriptions (1980-2010). Landline data are based on Canning for 1950-1989 and UN data from 1990-2010 while mobile phone subscription data are based solely on UN data. Sources: Canning 1998; United Nations Statistics Division (UNSD) 2014.

\section{Title: International tourism}

Unit: million arrivals

Caption: Number of international arrivals per year for the period 1950-2010.

Sources: Data for 1950-1994 are from UNWTO (United Nations World Tourism Organization) 2006 and data for 1995-2004 are from UNWTO 2011, data for 20052010 are from UNWTO 2014.

Figure 2. Trends from 1750 to 2010 for 10 of the socio-economic graphs (excluding primary energy use and international tourism) with three splits for: the OECD countries, the so-called BRICS (Brazil, Russia, India, China (including Macau, Hong Kong and Taiwan where applicable), and South Africa) countries, and the rest of the world 
Figure 3. Trends from 1750 to 2010 in indicators for the structure and functioning of the Earth System.

\section{Carbon dioxide}

Unit: parts per million

Caption: Carbon dioxide from firn and ice core records (Law Dome, Antarctica) and Cape Grim, Australia (deseasonalised flask and instrumental records); spline fit.

Source: D. Etheridge CSIRO, Australia; Etheridge et al. 1996; MacFarling Meure et al. 2004 and 2006; Langenfelds et al., 2011.

\section{Nitrous oxide}

Unit: parts per billion

Caption: Nitrous oxide from firn and ice core records (Law Dome, Antarctica) and Cape Grim, Australia (deseasonalised flask and instrumental records); spline fit.

Source: D. Etheridge CSIRO, Australia; MacFarling Meure et al. 2004 and 2006;

Langenfelds et al., 2011.

\section{Methane}

Unit: parts per billion

Caption: Methane from firn and ice core records (Law Dome, Antarctica) and Cape Grim, Australia (deseasonalised flask and instrumental records); spline fit.

Source: D. Etheridge CSIRO, Australia; Etheridge et al. 1998; MacFarling Meure et al. 2004 and 2006; Langenfelds et al., 2011.

\section{Stratospheric ozone}

\section{Unit: Percentage}

Caption: Maximum percentage total column ozone decline (2-year moving average) over Halley, Antarctica during October, using 305 DU, the average October total column ozone for the first decade of measurements, as a baseline.

Source: Data provided by J. D. Shanklin, British Antarctic Survey, UK. www.antarctica.ac.uk/met/jds/ozone/index.html\#data

\section{Surface temperature}

Unit: Degrees Celsius

Caption: Global surface temperature anomaly (HadCRUT4: combined land and ocean observations, relative to 1961-1990, 20 y Gaussian smoothed).

Source: P. Jones, Climatic Research Unit, UK in conjunction with the Hadley Centre (UK). http://www.cru.uea.ac.uk/cru/info/warming/gtc.csv

\section{Ocean acidification}

Unit: $\mathrm{nmol} \mathrm{kg} \mathrm{kg}^{-1}$

Caption: Ocean acidification expressed as global mean surface ocean hydrogen ion concentration from a suite of models (CMIP5) based on observations of atmospheric $\mathrm{CO}_{2}$ until 2005 and thereafter RCP8.5.

Source: James Orr, LSCE/IPSL, France; Bopp et al. 2013 and IPCC Fifth assessment report, Working Group 1, Chapter 6 (Ciais et al. 2013).

\section{Marine fish capture}

Unit: Million tonnes 
Caption: Global marine fishes capture production (the sum of coastal, demersal and pelagic marine fish species only), i.e., it does not include mammals, molluscs, crustaceans, plants etc. There are no FAO data available prior to 1950.

Source: Data is from the FAO Fisheries and Aquaculture Department online database (FAO-FIGIS 2013).

\section{Shrimp aquaculture}

Unit: Million tonnes

Caption: Global aquaculture shrimp production (the sum of 25 cultured shrimp species) as a proxy for coastal zone modification.

Source: Data is from the FAO Fisheries and Aquaculture Department online database FishstatJ (FAO 2013).

\section{Nitrogen to coastal zone}

\section{Unit: Mtons $\mathrm{yr}^{-1}$}

Caption: Model-calculated human-induced perturbation flux of nitrogen into the coastal margin (riverine flux, sewage and atmospheric deposition).

Source: Mackenzie et al., 2002.

\section{Tropical forest loss}

Unit: Percentage

Caption: Loss of tropical forests (tropical evergreen forest and tropical deciduous forest, which also includes the area under woody parts of savannas and woodlands) compared with 1700.

Source: Julia Pongratz, Carnegie Institution of Washington, Stanford, US; Pongratz et al. 2008. AD 1700 to 1992 is based on reconstructions of land use and land cover (Pongratz et al. 2008). Beyond 1992 is based on the IMAGE land use model.

\section{Domesticated land}

\section{Unit: Percentage}

Caption: Increase in agricultural land area, including cropland and pasture as a percentage of total land area.

Source: Julia Pongratz, Carnegie Institution of Washington, Stanford, US; Pongratz et al. 2008. AD 1700 to 1992 is based on reconstructions of land use and land cover (Pongratz et al., 2008). Beyond 1992 is based on the IMAGE land use model.

\section{Terrestrial biosphere degradation}

\section{Unit: Percentage}

Caption: Percentage loss of terrestrial mean species abundance relative to abundance in undisturbed ecosystems as an approximation for degradation of the terrestrial biosphere.

Source: R. Alkemade, PBL Netherlands Environmental Assessment Agency: modeled mean species abundance using GLOBIO3 based on HYDE reconstructed historical land use change estimates (until 1990) then IMAGE model estimates (Alkemade et al. 2009, www.globio.info, ten Brink et al., 2010). 


\section{References}

Alcamo J, Döll P, Henrichs T et al. (2003) Development and testing of the WaterGAP 2 global model of water use and availability. Hydrological Sciences Journal 48: 317337.

aus der Beek T, Flörke M, Lapola DM et al. (2010) Modelling historical and current irrigation water demand on the continental scale: Europe. Advances in Geoscience 27: 79-85 doi:10.5194/adgeo-27-79-2010.

Bai X, Shi P, Liu Y (2014) Realizing China’s urban dream. Nature 509: 158-160.

Bopp L, Resplandy L, Orr JC et al. (2013) Multiple stressors of ocean ecosystems in the $21^{\text {st }}$ century: projections with CMIP5 models. Biogeosciences 10: 6225-6245.

Barnosky AD, Hadly EA, Bascompte J et al. (2012) Approaching a state shift in Earth's biosphere. Nature 486: 52-58.

Canning D (1998) A Database of World Stocks of Infrastructure: 1950-1995. The World Bank Economic Review 12: 529-548.

Homepage: http://www.hsph.harvard.edu/david-canning/data-sets/

Data: http://cdn1.sph.harvard.edu/wp-content/uploads/sites/241/2012/10/telephone.xls

Ciais P, Sabine C, Bala G et al. (2013) Carbon and other biogeochemical cycles. In: Climate Change 2013: The Physical Science Basis. Contribution of Working Group I to the Fifth Assessment Report of the Intergovernmental Panel on Climate Change [Stocker, T. F., D. Qin, G.-K. Plattner, M. Tignor, S. K. Allen, J. Boschung, A. Nauels, Y. Xia, V. Bex and P. M. Midgley (eds.)]. Cambridge University Press, Cambridge, United Kingdom and New York, NY, USA, 2013.

Costanza R, Graumlich L and Steffen W (eds) (2006) Integrated History and Future of People on Earth, Dahlem Workshop Report 96, 495 pp.

Crutzen PJ (2002) Geology of mankind - the Anthropocene. Nature 415: 23

Crutzen PJ and Stoermer EF (2000) The “Anthropocene” IGBP Newsletter 41: 12.

Deutsch L, Troell M, Limburg K, Huitric M (2011) Global Trade of

Fisheries Products - Implications for marine ecosystems and their services. Ecosystem Services and Global Trade of Natural Resources, Ecology, Economics and Policies, ed Köllner T (Routledge, London), pp 120-147.

Edgeworth M, Richter D, Waters CN (2014) Diachronous beginnings of the Anthropocene: the stratigraphic bounding surface between anthropogenic and nonanthropogenic deposits. Quaternary International, submitted.

Etheridge DM, Steele LP, Langenfelds RL et al. (1996) Natural and anthropogenic changes in atmospheric $\mathrm{CO}_{2}$ over the last 1000 years from air in Antarctic ice and firn, Journal of Geophysical Research 101: 4115-4128. 
FAO (2013) Fishery and Aquaculture Statistics. Global aquaculture production 19502011 (FishstatJ). In: FAO Fisheries and Aquaculture Department online. Rome. http://www.fao.org/fishery/statistics/software/fishstatj/en. Accessed March 6, 2014: http://www.fao.org/fishery/statistics/global-aquaculture-production/en

FAO-FIGIS (2013) Fisheries and Aquaculture Information and Statistics Service In: FAO Fisheries and Aquaculture Department online. Rome. Accessed January 27, 2014: http://www.fao.org/fishery/statistics/global-capture-production/en.

FAOSTAT (2013) Database of the FAO (Food and Agriculture Organization of the United Nations). http://faostat.fao.org/. accessed 11/03/2013

FAOStat. Total Fertilizers consumption. Retrieved from http://faostat3.fao.org/download/R/RA/E (data accessed 25th November 2014)

FAOStat. Urban and Total population. Retrieved from http://faostat3.fao.org/download/O/OA/E (data accessed 25th November 2014)

Flörke M, Kynast E, Bärlund I et al. (2013) Domestic and industrial water uses of the past 60 years as a mirror of socio-economic development: A global simulation study. Global Environmental Change 23: 144-156

http://dx.doi.org/10.1016/j.gloenvcha.2012.10.018

Friedlingstein P, Andrew RM, Rogelj J et al. (2014) Persistent growth of CO2 emissions and implications for reaching climate targets. Nature Geoscience DOI:10.1038/NGEO2248

Galloway JN, Cowling EB (2002) Reactive nitrogen and the world: Two hundred years of change. Ambio 31: 64-71

Galloway JN, Townsend AR, Erisman JW, et al. (2008) Transformation of the nitrogen cycle: recent trends, questions, and potential solutions. Science 320: 889892.

Gattuso J-P and Hansson L (eds) (2011) Ocean acidification, Oxford University Press, 326pp.

Gerland P, Raftery AE, Ševčíková H et al. (2014) World population stabilization unlikely this century. Science DOI: 10.1126/science.1257469

Grubler A, Johansson TB, Mundaca L et al. (2012) Chapter 1 - Energy Primer p. 113 in Global Energy Assessment (GEA) - Toward a Sustainable Future, Cambridge University Press, Cambridge UK and the International Institute for Applied Systems Analysis, Laxenburg, Austria. DOI: http://dx.doi.org/10.1017/CBO9780511793677.

Hibbard KA, Crutzen PJ, Lambin EF et al. (2006) Decadal interactions of humans and the environment. In: Costanza R, Graumlich L and Steffen W (eds) Integrated History and Future of People on Earth, Dahlem Workshop Report 96, pp 341-375. 
Hönisch B, Ridgwell A, Schmidt, DN et al. (2012) The geological record of ocean acidification. Science 335: 1058. DOI: 10.1126/science.1208277

HYDE (History Database of the Global Environment) database. (2013) Netherlands Environmental Assessment Agency.

http://themasites.pbl.nl/tridion/en/themasites/hyde/basicdrivingfactors/population/inde x-2.html Accessed February 15, 2013.

IFA (International Fertilizer Industry Association) database. (2011)

http://www.fertilizer.org/ifa/ifadata/results. Accessed March 20, 2011 for data 1961 to 2008.

IMF (International Monetary Fund) (2013) http://elibrary-data.imf.org/ Accessed February 20, 2013.

IPCC (Intergovernmental Panel on Climate Change) (2013) Climate Change 2013: The Physical Science Basis. Summary for Policymakers. Alexander, L., Allen, S., Bindoff, N.L., Breon, F.-M., Church, J. et al., IPCC Secretariat, Geneva, Switzerland.

IRF (International Road Federation) (2011) World Road Statistics database.

Klein Goldewijk K, Beusen A and Janssen P (2010) Long-term dynamic modeling of global population and built-up area in a spatially explicit way: HYDE 3.1. The Holocene DOI: 10.1177/0959683609356587.

Klein Goldewijk K, Beusen A, de Vos M, van Drecht G (2011) The HYDE 3.1 spatially explicit database of human induced land use change over the past 12,000 years, Global Ecology and Biogeography 20: 73-86. DOI: 10.1111/j.14668238.2010.00587.x.

Langenfelds RL, Steele LP, Leist MA et al. (2011) Atmospheric methane, carbon dioxide, hydrogen, carbon monoxide, and nitrous oxide from Cape Grim flask air samples analysed by gas chromatography, Baseline 2007-2008, Australian Bureau of Meteorology and CSIRO Marine and Atmospheric Research, 62-66, 2011.

Le Quéré C, Raupach MR, Canadell JG et al. (2009) Trends in the sources and sinks of carbon dioxide. Nature Geoscience 2: 831-836.

Loutre M-F and Berger A (2000) Future climatic changes: are we entering an exceptionally long interglacial?, Climatic Change 46: 61-90.

MA (Millennium Ecosystem Assessment) (2005) Ecosystems and Human Well-being: synthesis. Washington, DC: Island Press.

MacFarling Meure C, Etheridge D, Trudinger $\mathrm{C}$ et al. (2006) The Law Dome $\mathrm{CO}_{2}$, $\mathrm{CH}_{4}$ and $\mathrm{N}_{2} \mathrm{O}$ ice core records extended to 2000 years BP. Geophysical Research Letters 33: L14810 10.1029/2006GL026152. 
MacFarling Meure C (2004) The natural and anthropogenic variations of carbon dioxide, methane and nitrous oxide during the Holocene from ice core analysis. $\mathrm{PhD}$ thesis, University of Melbourne.

Mackenzie FT, Ver LM and Lerman A (2002) Century-scale nitrogen and phosphorus controls of the carbon cycle. Chemical Geology 190: 13-32.

Maddison A (2001) The World Economy: A Millennial Perspective, OECD, Paris.

Maddison A (1995) Monitoring the World Economy 1820-1992, OECD, Paris. http://www.ggdc.net/maddison/Monitoring.shtml

Malm A and Hornborg A (2014) The geology of mankind? A critique of the Anthropocene narrative. The Anthropocene Review 1: DOI:

$10.1177 / 2053019613516291$

Marcott SA, Shakun JD, Clark PU and Mix AC (2013) A reconstruction of regional and global temperature for the past 11,300 years. Science 339: 1198-1201.

McNeill JR (2000) Something New Under the Sun: An Environmental History of the Twentieth-Century World. W. W. Norton \& Company: New York. 448 pp

Masson-Delmotte V, Schulz M, Abe-Ouchi A et al. (2013) Information from paleoclimate archives. In: Climate Change 2013: The Physical Science Basis. Contribution of Working Group I to the Fifth Assessment Report of the Intergovernmental Panel on Climate Change [Stocker, T. F., D. Qin, G.-K. Plattner, M. Tignor, S. K. Allen, J. Boschung, A. Nauels, Y. Xia, V. Bex and P. M. Midgley (eds.)]. Cambridge University Press, Cambridge, United Kingdom and New York, NY, USA, 2013.

Polanyi K (1944). The Great Transformation. Farrar \& Rinehart: New York.

Pongratz J, Reick C, Raddatz T and Claussen M. (2008) A reconstruction of global agricultural areas and land cover for the last millennium. Global Biogeochemical Cycles 22(GB3018): doi:10.1029/2007GB003153.

Rockström J, Steffen W, Noone K et al. (2009) Planetary Boundaries: Exploring the Safe Operating Space for Humanity. Ecology and Society 14: 32. [online] URL: http://www.ecologyandsociety.org/vol14/iss2/art32/

Rowland FS (2006) Stratospheric ozone depletion. Philosophical Transactions of the Royal Society of London. Series B 361: 769-790.

Ruddiman WF (2003) The anthropogenic greenhouse era began thousands of years ago. Climate Change 61: 261-293.

Ruddiman W, Vavrus S, Kutzbach J and He F (2014) Does pre-industrial warming double the anthropogenic total? The Anthropocene Review 1: 147-153. 
Seitzinger SP, Harrison JA, Dumont E et al. (2005), Sources and delivery of carbon, nitrogen, and phosphorus to the coastal zone: An overview of Global Nutrient Export from Watersheds (NEWS) models and their

application, Global Biogeochem. Cycles, 19, GB4S01, doi:10.1029/2005GB002606.

Seto KC (2010) The new geography of contemporary urbanization and the environment. Annual Review of Environment and Resources 35: 167-194

Seto KC, Guneralp B and Hutyra LR (2012) Global forecasts of urban expansion to 2030 and direct impacts on biodiversity and carbon pools. Proceedings of the National Academy of Sciences (USA) doi/10.1073/pnas.1211658109.

Shah T, Burke J, Villholth K et al. (2007) Groundwater: a global assessment of scale and significance. In: Molden D (ed) Water for Food, Water for Life, International Water Management Institute (IMWI) and Earthscan, London, pp 395-423.

Shane M (2014) United States Department of Agriculture (USDA) database: http://www.ers.usda.gov/datafiles/International_Macroeconomic_Data/Historical_Dat a_Files/HistoricalRealGDPValues.xlsAccessed October 9, 2014.

Sörlin S and Warde P (2009) Making the environment historical - an introduction. In: Nature's End: History and the Environment, Sörlin S and Warde P (eds.) Palgrave MacMillan, London, pp. 1-19.

Steffen W, Sanderson A, Tyson PD et al. (2004) Global Change and the Earth System: A Planet Under Pressure. The IGBP Book Series, Berlin, Heidelberg, New York: Springer-Verlag, 336 pp.

Steffen W, Crutzen PJ and McNeill JR (2007) The Anthropocene: Are humans now overwhelming the great forces of Nature? Ambio 36: 614-621.

Steffen W, Richardon K, Rockström J et al. (2014) Planetary boundaries: guiding human development on a changing planet. Science: in review.

ten Brink B, van der Esch S, Kram T and van Oorschot M (eds) (2010) Global MSA baseline scenarios, in Rethinking Global Biodiversity Strategies: Exploring Structural Changes in Production and Consumption to Reduce Biodiversity Loss, Netherlands Environmental Assessment Agency (PBL), The Hague/Bilthoven. http://www.globio.info/

Troell M, Naylor RL, Metian M et al. (2014) Does aquaculture add resilience to the global food system? Proceedings of the National Academy of Sciences (USA) 111: 13257-13263.

UN DESA (2014) http://esa.un.org/wpp/unpp/panel_population.htm

UNCTAD (United Nations Conference on Trade and Development) (2013) http://unctadstat.unctad.org/TableViewer/tableView.aspx Accessed February 20, 2013. 
UNFPA (2007) State of World Population 2007: Unleashing the Potential of Urban Growth. United Nations Population Fund, New York.

UNSD (United Nations Statistics Division) (2014) UNdata database. Land lines: http://data.un.org/Data.aspx?q=telephones\&d=MDG\&f=seriesRowID\%3a779 accessed 20140227. Mobile phones:

http://data.un.org/Data.aspx?q=cellular\&d=ITU\&f=ind1Code\%3aI271. Data accessed 20140228.

UNWTO (2006) (United Nations World Tourism Organization) Tourism Market Trends, 2006 Edition - Annex http://www.unwto.org/facts/eng/pdf/historical/ITA_1950_2005.pdf, Accessed: 9th October 2014

UNWTO (2011) UNWTO World Tourism Barometer. http://dtxtq4w60xqpw.cloudfront.net/sites/all/files/pdf/unwto_hq_fitur12_jk_1pp_0.p df . Accessed: 9th October 2014.

UNWTO (2014) UNWTO tourism highlights 2014 edition, http://dtxtq4w60xqpw.cloudfront.net/sites/all/files/pdf/unwto_highlights14_en.pdf, accessed: 09/10/2014,

Wilkinson RG, Pickett KE (2009) Income Inequality and Social Dysfunction. Annual Review of Sociology 35: 493-511.

WMO (World Meteorological Organization) (2014) Assessment for Decision-Makers: Scientific Assessment of Ozone Depletion: 2014, World Meteorological Organization, Global Ozone Research and Monitoring Project—Report No. 56, Geneva, Switzerland, 2014.

World Bank, World Development Indicators. Urban Population. Retrieved from http://data.worldbank.org/indicator/SP.URB.TOTL (data accessed 25th November 2014)

World Bank, World Development Indicators. Population, Total. Retrieved from http://data.worldbank.org/indicator/SP.POP.TOTL (data accessed 25th November 2014)

Zalasiewicz J, Crutzen P and Steffen W (2012). The Anthropocene. In: A Geological Time Scale 2012. Gradstein FM, Ogg JG, Schmitz M and Ogg GM (eds). Amsterdam: Elsevier. pp. 1033-1040 

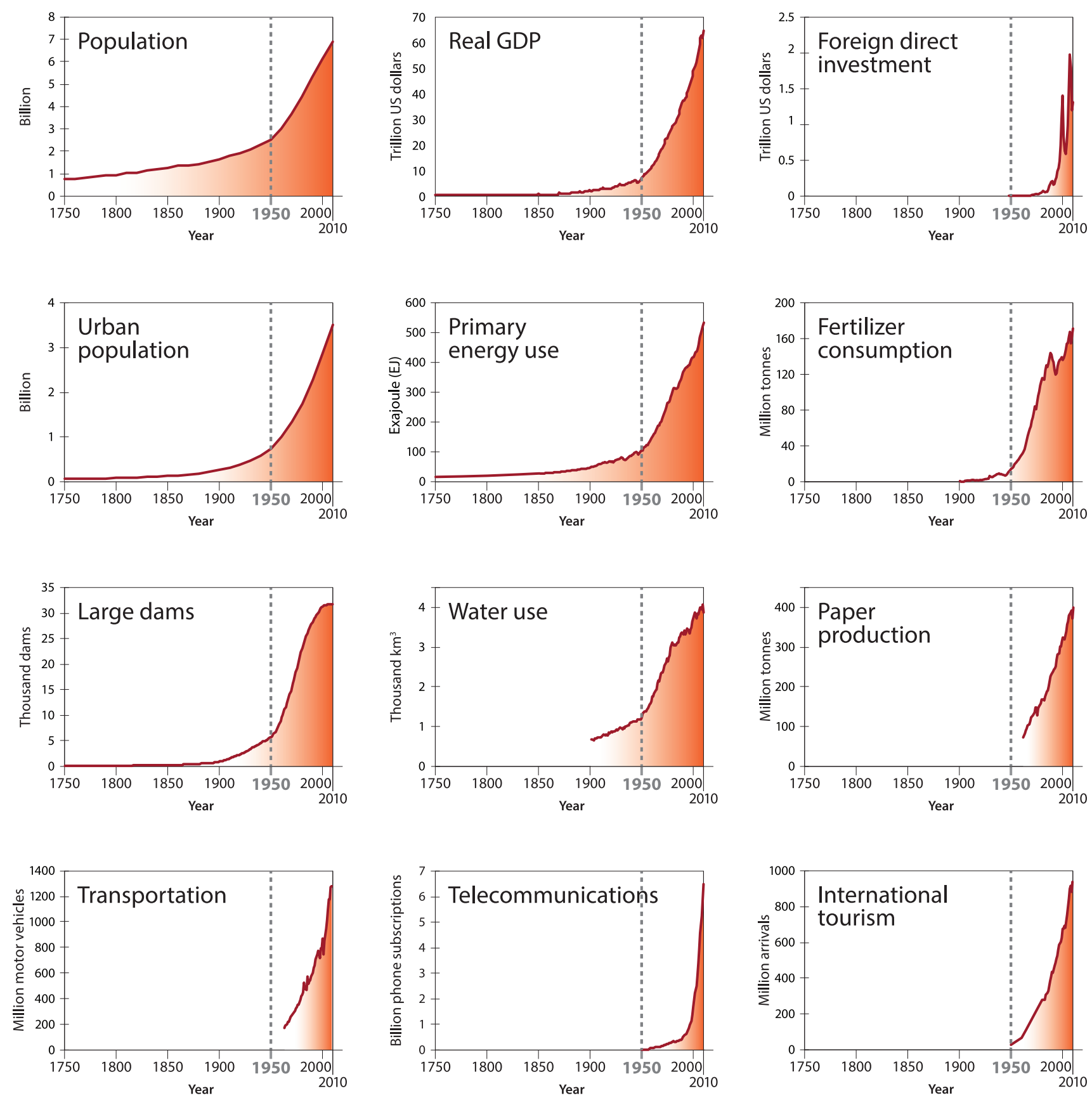

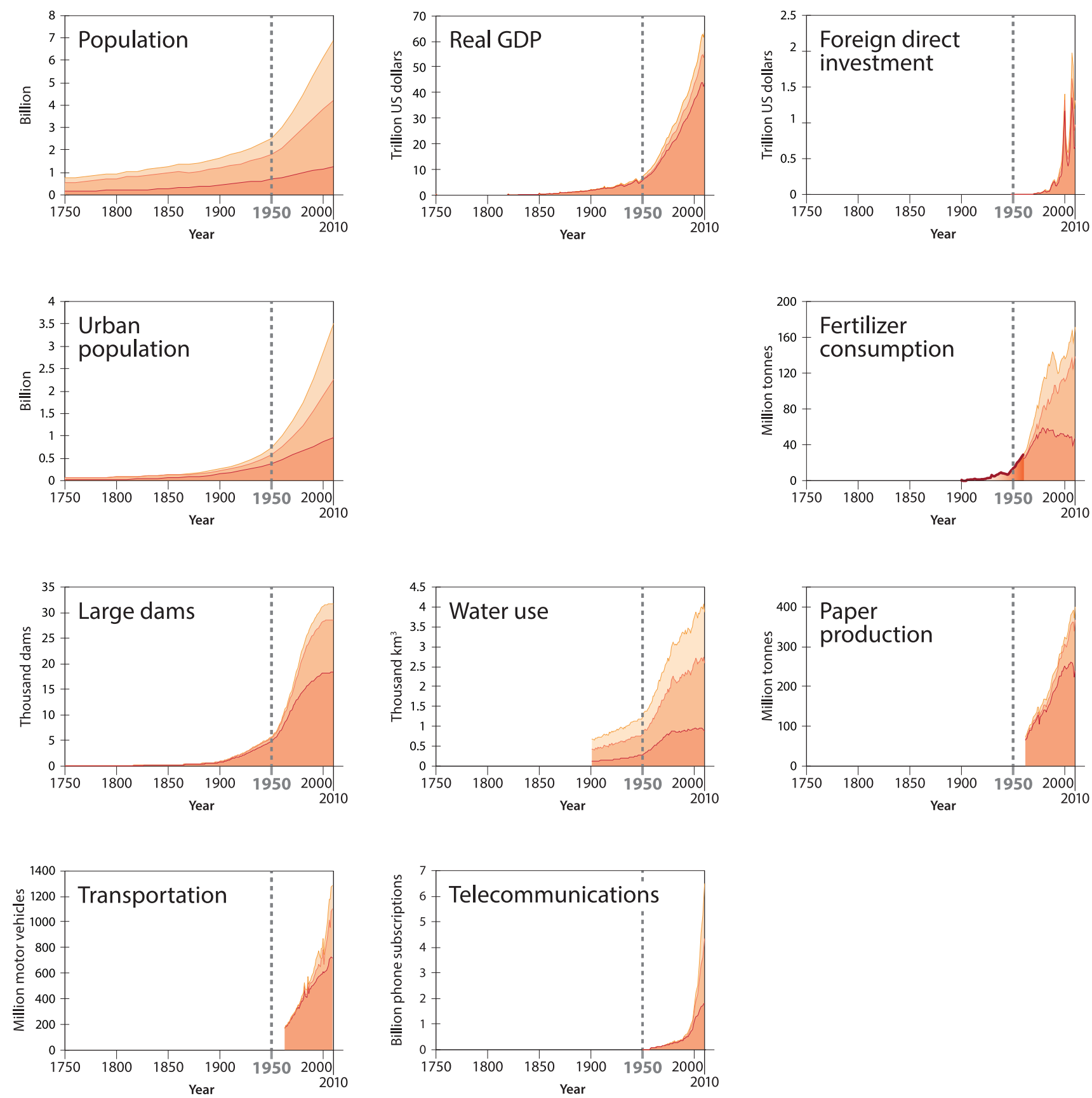


\section{Earth system trends}
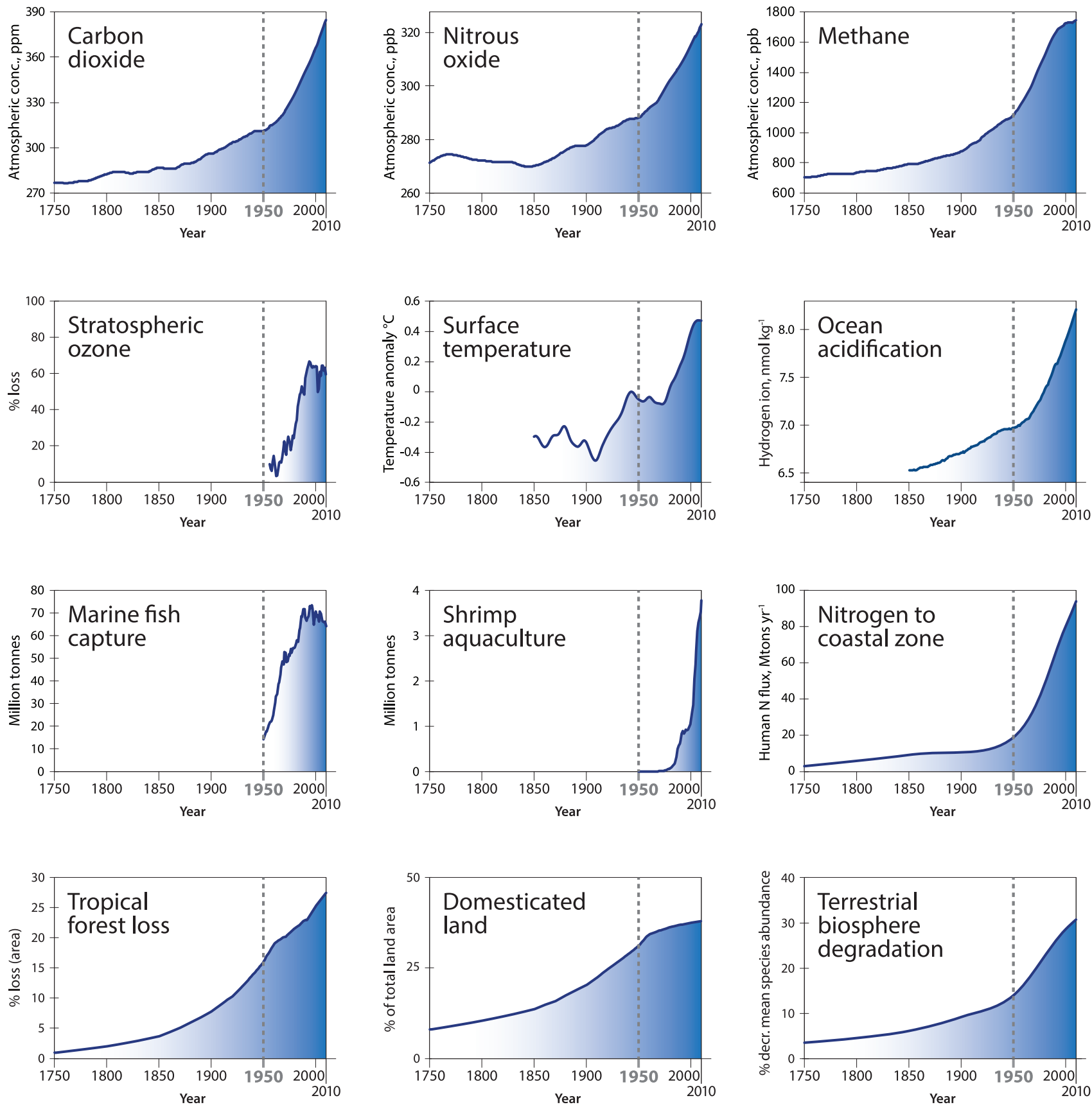